\title{
Analisis Minat dan Perkembangan Sarana dan Prasarana Olahraga Futsal pada Klub Opanindo di Kota Banda Aceh
}

\author{
Aldiansyah Akbar \\ Fakultas Keguruan dan Ilmu Pendidikan Universitas Serambi Mekkah \\ Email : aldiansyah.akbar@gmail.com
}

\begin{abstract}
Abstrak
Minat merupakan suatu hal yang sangat penting bagi setiap orang ketika melakukan aktivitas dalam rangka mencapai tujuan, ada bebrapa aspek penunjang lain untuk memperoleh prestasi dalam cabang olahraga futsal. Oleh kerena itu harus ada aspek penunjang yang memadai bagaimana sarana dan prasarana olahraga futsal harus tersedia dan terjaga. tujuan penelitian ini adalah untuk menganalisis minat dan perkembangan sarana dan prasarana olahraga futsal pada Klub Opanindo Di Kota Banda Aceh. Jenis penelitian yang digunakan pada penelitian ini adalah sejenis penelitian kualitatif deskriptif. Berdasarkan hasil penelitian dapat ditarik simpulan sebagai berikut:1) Minat pemain Klub Opanindo Di Kota Banda Aceh Minat pemain dalam olahraga futsal sangat baik sehingga pemain sangat antusia dalam melaksanakan kegiatan latihan dikarenakan hubungan pemain dan pelatih terjalin cukup dekat hal ini memudahkan pemain memiliki minat yang tinggi untuk berlatih dan bertanding. 2) Sarana dan prasarana yang dimiliki klub Opanindo cukup memadai Hal ini dapat dilihat dengan adanya lapangan sebagai tempat latihan, yang mesih harus berbagi dengan masyrakat sekitar tetapi cukup bagus dengan ketersediaan sarana yang lain seperti mesin potong rumput untuk merapikan lapangan tempat latihan, serta adanya bola, cone, rompi atau kostim latihan dan sarana dan prasarana lainnya. Dan semuanya itu merupakan sarana dan prasarana pendukung untuk mencapai prestasi yang baik.
\end{abstract}

\section{Kata kunci : minat, sarana dan prasarana, futsal}

\section{PENDAHULUAN}

Olahraga yang biasanya diikuti oleh para olahragawan. Cabang olahraga futsal merupakan olahraga yang memasyarakat yang digemari banyak kalangan, dari kalangan anak kecil sampai kalangan orang tua. Bermacam-macam tujuan dalam melakukan kegiatan olahraga futsal antara lain: a) olahraga untuk pencapaian prestasi, b) olahraga untuk kesehatan, c) olahraga untuk kebugaran, dan d) olahraga untuk rekreasi.

Minat adalah suatu perangsang keinginan dan daya penggerak kemauan bekerja seseorang, setiap motif minat mempunyai tujuan tertentu yang ingin dicapai (Hasibuan, 2005:95). Moekijat (dalam Hasibuan, 2005:95) menyatakan minat adalah suatu pengertian yang mengandung semua alat penggerak alasan-alasan atau dorongandorongan dalam diri manusia yang menyebabkan ia berbuat sesuatu. Menurut Barelson dan Steiner (dalam Hasibuan, 2005:95) sebuah minat adalah suatu pendorong dan dalam untuk beraktivitas atau bergerak dan secara langsung atau mengarah kepada sasaran akhir. Motivasi adalah kekuatan, baik dari dalam maupun dan luar yang mendorong seseorang untuk mencapai tujuan tertentu.

Minat merupakan suatu hal yang sangat penting bagi setiap orang ketika melakukan aktivitas dalam rangka mencapai tujuan. Menurut Maksum (2007:29) minat adalah sumber penggerak tingkah laku, dan dianggap sebagai disposi yang relatif setabil karena itu motivasi dipengaruhi oleh faktor pribadi. (Handoko, 2010: 43) juga 
menyatakan minat adalah penggerak tingkah laku manusia. Minat terbagi 2 macam yaitu minati intrinsik dan motivasi ekstrinsik.

Minati intrinsik adalah dorongan yang berasal dari dalam individu untuk melakukan sesuatu karena individu tersebut menikmatinya dan tidak memerlukan rangsangan dari luar untuk melakukannya. Macam-macam motivasi intrinsik terdiri dari aspek perasaan, aspek minat, aspek pengetahuan, aspek keterampilan, aspek kepuasan.

Motivasi ekstrinsik adalah dorongan atau motif yang berasal dari luar individu untuk melakukan sesuatu, karena adanya rangsangan dari luar atau tujuan yang ingin dicapai. Macam minati ekstrinsik terdiri dari aspek penghargaan, aspek kompetisi, aspek hadiah, aspek pujian, aspek hukuman, dan aspek lingkungan.

Bukan hanya minat sebagia aspek utama ada bebrapa aspek penunjang lain untuk memperoleh prestasi dalam cabang olahraga futsal tentunya tidak mudah, seperti yang diungkapkan oleh Sajoto bahwa, "untuk mencapai suatu prestasi dalam olahraga, merupakan suatu usaha yang benar-benar harus diperhitungkan secara masak dengan suatu usaha pembinaan melalui pembinaan secara dini”. Anwar Pasau yang disadur oleh Sajoto menjelaskan, "terdapat beberapa aspek penentu dalam pencapaian prestasi olahraga, yaitu: 1. Aspek biologis, 2. Aspek psikologis, 3. Aspek lingkungan, 4. Aspek penunjang".

Oleh kerena itu harus ada aspek penunjang yang memadai bagaimana sarana dan prasarana olahraga futsal harus tersedia dan terjaga, Fasilitas dan sarana olahraga futsal bagi masyrakat adalah tersedianya sarana dan prasarana yang digunakan untuk mencapai tujuan dari proses kegiatan dan tujuan olahraga futsal itu sendiri. Sarana prasarana olahraga futsal adalah suatu bentuk permanen, baik itu ruang di luar maupun di dalam. Contoh: lapangan permainan, ruang kamar ganti, dsb. Pengertian sarana prasarana adalah sumber daya pendukung yang terdiri dari segala bentuk jenis bangunan/tanpa bangunan yang digunakan untuk perlengkapan olahraga futsal. Sarana prasarana olahraga yang baik dapat menunjang pertumbuhan masyarakat yang baik.

Penilain tentang keadaan sarana dan prasarana olahrga futsal juga dinilai oleh salah satu tim futsal yang ada di banda aceh, klub futsal Opanindo yang dalam pembentukannya banyak melahirkan tunas muda pemain futsal. Opanindo memiliki pemain yang telah mempunyai kemampuan dan keahlian dalam bermaian futsal. Kemampuan para pemain telah teruji melalaui beberapa turnamen futsal yang telah meraka ikuti.

Berdasarkan permasalahan yang telah diuraikan diatas, peneliti tertarik dan berkeinginan untuk melakukan sebuah penelitian yang bertujuan untuk mengetahui jawaban dari permasalahan tersebut, sehingga penulis berkeinginan untuk melakukan sebuah penelitian yang berjudul "Analisis Minat dan Perkembangan Sarana dan Prasarana Olahraga Futsal pada Klub Opanindo di Kota Banda Aceh".

\section{Tujuan Penelitian}

Tujuan penelitian ini untuk mengetahui analisis minat dan perkembangan sarana dan prasarana olahraga futsal pada klub Opanindo di Kota Banda Aceh.

\section{TINJAUAN PUSTAKA}

\section{Sarana Olahraga Futsal}

Sarana olahrag futsal merupakan peralatan yang sangat membantu dalam proses kegiatan permainan futsal. Sarana kegiatan pada dasarnya merupakan segala sesuatu yang sifatnya tidak permanen, dapat dibawa kemana-mana atau dipindahkan dari satu 
tempat ketempat yang lain. Menurut Sadily dalam Kamus Besar Bahasa Indonesia (1993) di jelaskan, "Sarana adalah segala sesuatu yang dipakai sebagai alat dalam mencapai maksud dan tujuan". Contoh: Bola, tiang gawang, kun, sarung tangan kiper, d1l. Sarana atau alat sangat penting dalam memberikan motivasi kepada para atlit dengan sungguh-sungguh dan akhirnya tujuan kegiatan olahraga dapat tercapai.

Alat-alat olahraga futsal biasanya di pakai dalam waktu relative pendek minsalnya: bola, jaring gawang, sepatu dan sebagainya. Alat-alat olahraga biasanya tidak dapat bertahan dalam waktu yang lama, alat akan rusak apabila sering di pakai dalam kegiatan latihan, agar alat dapat bertahan lama haruslah di rawat dengan baik. sarana maupun alat merupakan benda yang di butuhkan dalam kegiatan olahraga, dan alat tersebut sangat mudah dibawa sehingga sarana atau alat tersebut sangat praktis dalam pelaksanaan kegiatan olahraga. Alat olahraga merupakan hal yang mutlak harus di miliki oleh setiap klub futsal, tanpa di tunjang dengan hal ini proses latihan tidak akan dapat berjalan dengan baik. Sedangkan menurut Sukintaka (2001:21) yang di maksud alat adalah: alat merupakan yang di gunakan dalam olahraga, misalnya bola untuk bermain futsal, voli, sepak bola dan peralatan lainnya yang menunjang dalam kegiatan olahraga.

Berdasarkan pengertian sarana yang di kemukakan beberapa ahli tersebut dapat di simpulkan bahwa, sarana olahraga futsal merupakan perlengkapan yang mendukung kegiatan olahraga futsal yang sifatnya dinamis dapat berpindah-pindah dari satu tempat ke tempat yang lain, misalnya bola, jaring gawang dan sarana atau alat yang merupakan segala sesuatu yang dipergunakan dalam proses kegiatan olahraga futsal berlangsung.

\section{Manfaat Sarana Olahraga Futsal}

Manfaat sarana olahraga futsal adalah dapat meningkatkan kualitas kesehatan dan keterampilan serta mendukung berlangsungnya perlombaan dan pertandingan. Sarana dan prasarana pembelajaran olahraga futsal merupakan salah satu dari alat dan tempat kegiatan berlangsung, di mana sarana dan prasarana mempunyai peran yang penting dalam proses aktivitas olahraga. Pemanfaatan sarana dan prasarana yang dilakukan oleh para pelaku olahraga dalam situasi kegiatan menunjang tercapainya tujuan olahraga itu sendiri. Proses kegiatan akan mengalami kepincangan atau tersendat-sendat bahkan proses kegiatan bisa berhenti sama sekali. Bisa dinyatakan bahwa sarana dan prasarana olahraga ini sebagai alat bantu dalam penujang aktivitas keolahragaan.

\section{Prasarana Olahraga Futsal}

Prasarana olahraga futsal pada dasarnya merupakan sesuatu yang bersifat permanen. Kelangsungan proses kegiatan olahraga futsal tidak terlepas dari tersedianya prasarana yang baik yang memadai. Prasarana yang baik dan memadai maka proses aktivitas olahraga yang dapat berjalan dengan baik. Menurut Soepartono (2000:5) berpendapat bahwa "Prasarana olahraga adalah sesuatu yang merupakan penunjang terlaksananya suatu proses aktivitas olahraga". Dalam olahraga futsal prasarana di definisikan sebagai sesuatu yang mempermudah atau memperlancar proses kegiatan permainan berlangsung. Salah satu sifat yang dimiliki oleh prasarana olahraga futsal adalah sifatnya yang relative permanen atau susah untuk di pindah. Menurut Depdiknas dalam Kamus Besar Bahasa Indonesia (2001:893) bahwa "prasarana adalah segala sesuatu yang merupakan penunjang utama terselenggaranya suatu proses usaha, pembagunan obyek dan lain sebagainya. 
Prasarana pendidikan jasmani yang di maksud dalam pendapat di atas dapat diartikan sebagai prasarana dengan ukuran standar seperti lapangan-lapangan maupun gedung olahraga, tetapi kebanyakan klub futsal tidak dapat menyengarakan kegiatan latihan dengan prasarana standar, sebagian dapat mengunakan prasarana standar yang terdapat di sekitar lingkungan tempat terbuka atau umum namun harus berbagi dengan yang lain maupun masyarakat.

Lebih lanjut Wirjasantosa (2011: 134) mengungkapkan bahwa, "Fasilitas olahraga adalah suatu bentuk yang permanen, baik untuk ruangan didalam maupun di luar. Misalnya: gymnasium (ruang senam), kolam renang, lapangan-lapangan permainan, dan sebagainya". Sebagai bahan perbandingan, UNESCO juga telah merekomendasikan bahwa "Ruang gerak statis yang ideal adalah lebih kurang $2 \mathrm{~m} 2$ per orang. Jika olahraga membutuhkan ruang gerak yang bukan statis melainkan dinamis, maka dapat dianalogikan ruang gerak yang diperlukan adalah dua kali ruang gerak statis yaitu lebih kurang $4 \mathrm{~m} 2$." Sementara itu, Clerici (2001) berpendapat bahwa : angka standar ruang terbuka adalah $3,5 \mathrm{~m} 2$ per orang. Hal ini didasarkan pada argumentasi bahwa kelompok penduduk yang terdiri dari 3500 orang dapat menggunakan sekurang-kurangnya $12.000 \mathrm{~m} 2$ ruang terbuka untuk kegiatan olahraga.

\section{Pengertian Futsal}

Futsal berasal dari bahasa Spanyol yaitu "Futebol Sala" yang artinya Sepakbola Ruangan. Permaian ini di lakukan oleh 5 vs 5 pemain sudah termasuk kiper, berbeda dengan six soccer yang dimainkan oleh 5 vs $5+1$ kiper $=6$ pemain, futsal dimainkan di atas lantai kayu, semen dan rumput sintesis yang sedang „,ngetren ${ }^{\text {ee }}$ di Indonesia, tetapi untuk pertandingan resmi internasional biasanya dimainkan di atas lantai berbahan rubber atau vinyl berwarna biru muda. Futsal awalnya lebih sering dimainkan tanpa peraturan, hanya kesepakatan antara tim yang satu dengan lawannya.

Butuh waktu hamper dua dasawarsa untuk membuat futsal lebih diakui. Kesulitan timbul saat beberapa tokoh futsal di Sao Paulo berniat mengembangkan dan menyebarluaskan futsal. Pada 1935, dimulailah pertemuan marathon untuk merumuskan aturan baku tentang bagaimana futsal dimainkan. Kesepakan pertama dibuat. Karena kondisi,terutama luas lapangan, harus ada perbedaan peraturan antara futsal dengan sepakbola. Akhirnya pada pertengahan 1936, sekumpulan orang itu mengeluarkan peraturan futsal yang pertama di dunia. Isinya tidak beda jauh dengan peraturan FIFA yang ada sekarang.

Pada 1954, aturan tentang futsal di bakukan. Perkembangan futsal di Brasil pun semakin pesat. Futsal menyebar ke Eropa karena perpindahan pemain dari Amerika Selatan ke daratan Eropa, orang-orang dari Amerika Selatan mengenalkan permainan futsal kepada masyarakat Eropa, secara perlahan futsal akhirnya digemari oleh masyarakat eropa. Pada tahun 2002 Indonesia telah berhasil menyelenggarakan Kejuaraan Futsal Asia di Jakarta. Pada saat itulah lahir timnas Futsal Indonesia yang pertama kali masih di huni oleh pemain sepakbola dari klub liga Indonesia. Akan tetapi pada saat ini futsal telah mengalami perkembangan yang luar biasa, hal itu terlihat dari banyaknya bermunculan penyewaan lapangan futsal di Jakarta dan kota besar lainnya dan juga turnamen-turnamen futsal di Jakarta.

\section{METODE PENELITIAN}

Jenis penelitian yang digunakan pada penelitian ini adalah sejenis penelitian kualitatif deskriptif. Jenis penelitian ini adalah penelitian deskriptif. Suharsimi Arikunto (2006: 302). menyatakan bahwa "penelitian deskriptif tidak dimaksudkan 
untuk menguji hipotesis tertentu, tetapi hanya menggambarkan "apa adanya" tentang sesuatu variabel, gejala atau keadaan". Data yang dikumpulkan dalam penelitian ini adalah data yang berupa angka, sehingga penelitian ini disebut penelitian deskriptif kuantitatif. Metode yang digunakan adalah survei.

Menurut Suharsimi Arikunto (2006: 312), metode survei merupakan penelitian yang biasa dilakukan dengan subjek yang banyak, dimaksudkan untuk mengumpulkan pendapat atau informasi mengenai status gejala pada waktu penelitian berlangsung.

\section{Rancangan Penelitian}

Rancangan penelitian adalah tahapan atau rencana tentang bagaimana proses pengumpulan data pada objek penelitian sehingga data yang diperoleh sesuai dengan standar penelitian untuk pendidikan yang sesuai dengan literatur dan mempunyai nilai kepercayaan yang tinggi. Dalam penelitian ini penelitian menggunakan rancangan penelitian pendekatan studi potong lintang (Cross Sectional Study), yaitu suatu rancangan penelitian dimana pengumpulan data dilakukan sekaligus dalam suatu waktu.

\section{Subjek Penelitian}

Subjek adalah keseluruhan dari penelitian (Arikunto 2010:173). Dari pendapat di atas, penulis menyimpulkan bahwa Subjek seluruh individu yang akan dijadikan subjek penelitian dan keseluruhan dari individu-individu yang harus memiliki sifat yang sama yaitu Seluruh Atlit Olahraga Futsal Klub Opanindo.

\section{Objek Penelitian}

Objek dalam penelitian ini peneliti menggunakan teknik total sample atau yaitu teknik dimana subjek dijadikan sampel yang berjumlah 7 orang Atlit Opanindo.

\section{Tabel Sampel Penlitian Tim Futsal Opanindo}

\begin{tabular}{|l|l|l|}
\hline No. & Nama & Posisi \\
\hline 1 & Irfan Mirza & Kiper \\
\hline 2 & Mirza Aulia & Anchor \\
\hline 3 & Khairul Aulia & Pivot \\
\hline 4 & Fadil Arjuna & Pivot \\
\hline 5 & Amir & Flank \\
\hline 6 & Ade tama & Pelatih \\
\hline 7 & Tengku Rizal & Pembina \\
\hline
\end{tabular}

(Sumber : Sekretaris Tim Futsal Opanindo Tahun 2020)

\section{Teknik Pengumpulan Data}

Teknik pengumpulan data yang digunakan dalam penelitian ini adalah:

a. Instrumen

Instrumen penelitian yang digunakan dalam penelitian ini yaitu wawancara

b. Wawancara

Wawancara dalam penelitian ini digunakan dan diajukan kepada sampel penelitain, untuk mengetahui bagaimana Analisis Minat Dan Perkembangan Sarana Dan Sarana Pada Klub Opanindo.

\section{Teknik Analisis Data}

Teknik Analisis data menurut Bogdan dalam Sugiyono (2009: 244) adalah 
proses mencari dan menyusun secara sistematis data yang diperoleh dari hasil wawancara, catatan lapangan, dan bahan-bahan lain, sehingga dapat mudah dipahami, dan temuannya dapat diinformasikan kepada orang lain.

Proses analisis yang digunakan dalam penelitian ini ialah dengan menggunakan model Miles dan Huberman dalam Prastowo (2012:242) yaitu melalui proses reduksi data, penyajian data, penarikan simpulan dan triangulasi.

1. Reduksi Data (Data Reduction)

Reduksi data merupakan suatu proses pemilihan, pemusatan perhatian pada penyerderhanaan, pengabstrakan, dan transformasi data awal yang muncul dari catatan catatan tertulis di lapagan.

2. Penyajian Data (data display)

Penyajian data yang lazin digunakan dalam penelitian ini adalah bantuk teks naratif. Maksud dari teks naratif penelitian mendeskripsikan informasi yang telah diklasifikasikan sebelumnya mengenai Analisis Minat Dan Perkembangan Sarana Dan Prasarana Pada Klub Opanindo Tahun 2020. yang kemudian dibentuk simpulan dan selanjutnya simpulan tersebut disajikan dalam bentuk teks naratif.

3. Penarikan Simpulan (conclusion verying)

Penelitian berusaha menarik simpulan dan melakukan verifikasi dengan mencari makna setiap gejala yang diperolehnya dari lapagan, mencatat keteraturan dan konfigurasi yang mungkin ada, alur kausalitas dari fenomena dan proporsi. Pada tahap ini, penulis menarik simpulan data yang telah disimpulkan sebulumnya, kemudian mencocokan catatan dan pengamatan yang dilakukan penulis pada saat penelitian.

4. Triangulasi (data)

Triangulasi adalah teknik pemeriksa data untuk keperluan pengecekan atau sebagai pembanding terhadap data yang telah diperoleh.

\section{HASIL PENELITIAN DAN PEMBAHASAN}

Dari hasil penelitian yang diperoleh dengan cara melakukan pendekatan wawancara Pada Klub Opanindo di Kota Banda Aceh Tahun 2020 dengan jabaran beberapa indikator yang akan di uraikan dalam pelaksanaan wawancara yang dilakukan dengan melibatkan pemain klub Opanindo di Kota Banda Aceh Tahun 2020, untuk mendapatkan jawaban dari pertanyaan penelitian tentang Analisis Minat Dan Perkembangan Sarana Dan Prasarana Olahraga Futsal Pada Klub Opanindo Di Kota Banda Aceh dengan uraian sebagai berikut:

\section{Deskripsi Data Hasil Wawancara Dengan Pemain Klub Opanindo}

Dari hasil penelitian yang diperoleh dengan cara melakukan pendekatan wawancara pada Klub Opanindo Kota Banda Aceh dengan jabaran beberapa indikator yang akan di uraikan dalam pelaksanaan wawancara yang dilakukan dengan melibatkan pemain pemain dapat di tarik kesimpulan sebagai berikut bahwa pembinaan yang dilakukan pihak klub sangat baik, pola pembinaan yang terukur mempermudahkan pemain dalam beradaptasi dan minat pemain terhadap olahrga ini semakin tinggi sehingga pembinaan berjalan dengan arahan yang teratur dan fasilitas yang memadai.

\section{Deskripsi Data Hasil Wawancara Dengan Pelatih Klub Opanindo}

Dari hasil penelitian yang diperoleh dengan cara melakukan pendekatan wawancara pada Klub Opanindo Kota Banda Aceh dengan jabaran beberapa indikator yang akan di uraikan dalam pelaksanaan wawancara yang dilakukan dengan melibatkan pelatih Ade tama aulia. Dapat di tarik kesimpulan bahwa pelatih merupakan orang 
terdekat dari pemain dan pembina sehingga tugas pelatih memberikan dorongan yang kuat kepada pemain dan memberikan sarana dan prasarana terbaik untuk pemain melalui kedekatan pelatih ke pada pembina.

\section{Deskripsi Data Hasil Wawancara Dengan Pembina Klub Opanindo}

Dari hasil penelitian yang diperoleh dengan cara melakukan pendekatan wawancara pada Klub Opanindo Kota Banda Aceh dengan jabaran beberapa indikator yang akan di uraikan dalam pelaksanaan wawancara yang dilakukan dengan melibatkan pembina bapak Tengku rizal. Dapat di tarik kesimpulan bahwa pembina mempunyai peran besar dalam klub ini sehingga pihak klub juga memberikan yang terbaik untuk pemain dan juga pelatih.

\section{Pembahasan}

Pembahasan hasil penelitian adalah sebagai berikut, Dari hasil yang wawancara yang dilakukan bahwa didirikannya Klub Opanindo adalah dengan tujuan untuk menggembangkan bakat anak-anak di Kota Banda Aceh khusnya di bidang futsal agar mendapatkan arahan yang terencana dan teprogram untuk meningkatkan prestasi futsal yang berada di Kota Banda Aceh.

Pada saat didirikan dan dibentuk kepengurusanya sudah lengkap dimana ketua, seketaris, bendahara, pelatih, dan seksi-seksi yang lain di pilih melalui musyawarah yang dilakukan pihak klub, berdasarkan temuan lapangan dan analisis organisasi klub opanindo yang dideskripsikan melalui manajemen dan prasarana yang menunjang, serta sistem yang baik yang mempunyai faktor pendukung seperti minat pemain dan pelatih dan pembina.

Sedangkan menurut Drs. Dyimyati Mahmud (1982), Minat dalah sebagai sebab yaitu kekuatan pendorong yang memaksa seseorang menaruh perhatian pada orang situasi atau aktifitas tertentu dan bukan pada yang lain, atau minat sebagai akibat yaitu pengalaman efektif yang distimular oleh hadirnya seseorang atau sesuatu obyek, atau karena berpartisipasi dalam suatu aktifitas.

Beberapa pendapat yang dikemukakan tersebut diatas, penelitian dapat menarik kesimpulan bahwa minat adalah kecenderungan hati seseorang yang terarah kepada suatu objek tertentu yang dinyatakan dalam berbagai tindakan, karena adanya suatu perhatian dan perasaan tertarik pada objek.

Sejalan dengan fakta yang terjadi di opanindo kota banda aceh sesuai dengan pendapat (Wirjasanto 2000:154). Menjelaskan Sarana prasarana olahraga adalah semua sarana prasarana olahraga yang meliputi semua lapangan dan bangunan olahraga beserta perkengkapannya untuk melaksanakan program kegiatan olahraga. Sarana olahraga adalah sumber daya pendukung yang terdiri dari segala bentuk dan jenis peralatan serta perlengkapan yang digunakan dalam kegiatan olahraga. Prasarana olahraga adalah sumber daya pendukung yang terdiri dari tempat olahraga dalam bentuk bangunan di atasnya dan batas fisik yang statusnya jelas dan memenuhi persyaratanyang ditetapkan untuk pelaksanaan program kegiatan olahraga. Dari beberapa pengertian di atas dapat diartikan bahwa sarana prasarana olahraga adalah sumber daya pendukung yang terdiri dari segala bentuk jenis bangunan/tanpa bangunan yang digunakan untuk perlengkapan olahraga.

\section{Kesimpulan}

Berdasarkan hasil penelitian tentang, Tingkat Analisis Minat Dan Perkembangan Sarana Dan Prasarana Olahraga Futsal Pada Klub Opanindo Di Kota Banda Aceh Tahun 
2020 maka dapat ditarik simpulan sebagai berikut : Minat pemain Klub Opanindo Di Kota Banda Aceh Tahun 2020 Minat pemain dalam olahraga futsal sangat baik sehingga pemain sangat antusia dalam melaksanakan kegiatan latihan dikarenakan hubungan pemain dan pelatih terjalin cukup dekat hal ini memudahkan pemain memiliki minat yang tinggi untuk berlatih dan bertanding. Sarana dan prasarana yang dimiliki klub Opanindo cukup memadai Hal ini dapat dilihat dengan adanya lapangan sebagai tempat latihan, yang mesih harus berbagi dengan masyrakat sekitar tetapi cukup bagus dengan ketersediaan sarana yang lain seperti mesin potong rumput untuk merapikan lapangan tempat latihan, serta adanya bola, cone, rompi atau kostim latihan dan sarana dan prasarana lainnya. Dan semuanya itu merupakan sarana dan prasarana pendukung untuk mencapai prestasi yang baik.

\section{DAFTAR PUSTAKA}

Ali Maksum (2007) Sport Development Indeks. Jakarta,. PT. Indeks.

Depdiknas. 2000. Kamus Besar Bahasa Indonesia edisi Ketiga. Jakarta: Balai Pustaka. Hasibuan, S.P Malayu (2005). Manajemen Sumber Daya Manusia. Edisi Revisi. Jakarta : Bumi Aksara.

Handoko, T. Hani. (2010). Manajemen Personalia \& Sumber daya Manusia. BPFEYogyakarta.

Sukintaka. (2001). Teori Pendidikan Jasmani. Yogyakarta: FPOK IKIP. Yogyakarta.

Soepartono. 2000. Sarana dan Prasarana Olahraga, Departemen Pendidikan dan. Kebudayaan Direktorat Jenderal Pendidikan Dasar dan Menengah.

Sugiyono, Metode Penelitian Pendidikan: Pendekatan Kuantitatif, Kualitatif dan R\&D (Bandung: Alfabeta, 2009) hal. 6

Suharsimi , Arikunto. (2002). Prosedur penelitian suatu pendekatan Praktek. Jakarta: PT Rineks Cipta. 